obtained. This excellent book provides the essential background training and anyone contemplating the use of polarography for research or analysis would be well advised to read it and work through some of the experiments beforehand.

B. Fleet

\section{ANTHOLOGY OF SCIENTISTS}

\section{A Biographical Dictionary of Scientists}

Edited by Trevor I. Williams, assisted by Sonia Withers. Pp. xi+592. (Black: London, January 1969.) 100s.

There can be few tasks more riddled with dilemmas than the compilation of a dictionary of scientists which aims to be both comprehensive and yet free of the scourge of perpetual digression. That the Biographical Dictionary of Scientists manages to achieve a healthy synthesis of these two ends owes as much to the fact that the contributors have adhered consistently to a prescribed formula for the inclusion of individual scientists as to their actual criterion for such inclusions.

Who can fairly be described as a scientist? What asprets of a scientist's life demand inclusion in a book which sets out to allot one and a half pages to such a dramatic and vital life as that of Einstein, or a mere one page to the pioneering spirit embodied in the life of Ehrlich? Should a person who dabbled in science but whose main prowess was exhibited in some other field of endeavour be included to the exclusion of some slightly more science-bent if less illustrious individual ? And if so, should their lives be described in a depth appropriate to their overall fame or to their achievements in science ?

The editor has attempted to resolve these questions by selecting one of the many arbitrary but sensible options open to him, although questionably the most logical of the options.

The subject matter embraced by the heading "Science" has been chosen to include engineering, agriculture, medicine and mathematics as well as the conventional science subjects. It is difficult to quibble with this. Where the editor treads on slightly softer ground is in allowing persons like Leonardo da Vinci to claim as much space as some of the giants of the science world, although many people will no doubt excuse this on the grounds of the intrinsic interest of such a unique figure.

The biographies are focused around the scientific achievements of the subjects, with excursions into family or political activities and educational background. The most important dates, discoveries, theories or inventions of each scientist are covered in a style which is as objective as can reasonably be expected in any biography, and, by and large, the information given is both interesting and relevant. Technical language has successfully been avoided in all but the most necessary places.

Considerable pains have been taken to set up a system of referenees which an enthusiast can pursue should he so wish, and cross-references abound between scientists whose work or lives overlap. An appendix has been added which lists more than 700 scientists who have not been given individual mention but whose names occur in the biographies of those who have.

The dictionary has been compiled by fifty contributors, each an expert in his own subject. There do not appear to be any serious omissions from the list of entries, although the choice of which middle ranking scientists ought to have been included is bound to be a question of opinion.

'The philosophical and engineering fringes of science seem to be those most open to argument. That Descartes should be given full honours is beyond dispute, but whether someone like Locke, whose flirtation with science was very peripheral, or Heathcote, whose inventions require some imagination to allow him to be termed a scientist, should be given eoverage is open to serious doubt.
The biographies are not without their lighter moments, which is all to the good, but there are some anomalies in this regard. Why Lindemann's tennis ability should take precedence over Einstein's musical skill is a matter of conjecture. In general, however, this book should be a useful addition to the shelves of any scientist, and could certainly make for a stimulating "thumbing through" by many people whose prime interest is outside the scientific orbit.

Andrew Miluington

\section{Correspondence}

\section{Medical Teachers' Pay}

Sin,--The recent report by the Prices and Incomes Board dated December 1968 on the pay of university teachers recommended that medical teachers with consultant contracts should be paid the same salary as their National Health Service consultants. Since this report was published there has been considerable discussion about the method of assimilation on to the new scales.

The first instruction to the universities by the UGC was that the medical teacher should be assimilated on to the nearest point on the NHS scale except where this was less than his current salary, in which case he would retain his present salary until the next inerement was due.

Following further consideration of this problem, which has included consultation with the Prices and Incomes Board, the UGC has now issued a modified instruction to the universities which states that medical teachers should be assimilated to the next higher point on the NHS consultant scale in relation to the salary in payment on October 1, 1968, except that, where there is a point on the NHS scale exactly equivalent to the salary in payment, assimilation should be to that point. These proposals create the following grave defects.

(1) They do not offer even apparent parity of salary between NHS and university except for newly appointed staff and those with less than one year's service. The maximum disparity arises in the case of a senior lecturer with nine years' service, who is paid $\$ 945$ less than an NHS consultant of similar service. (2) The increases are inequitable, ranging from 16 per cent for some staff to nil for others. (3) The method of assimilation disrupts the existing salary structure for staff with less than four years' service, who will all receive the same salary as newly appointed staff. (4) The method of assimilation is unprecedented, being totally dissimilar to the previous method adopted when a similar situation arose at the assimilation of colleges of advanced technology into universities. The new proposals are unique in that they discriminate against staff already in post.

The repereussions of these proposed salaries can only be the subject of conjecture, but the following points seem worth emphasizing. (a) True parity of salary between NHS and university will effectively be postponed for many years because the starting salary for newly appointed staff will tend to be restricted by the salary structure of those already in post. (b) The proposals will alienate the goodwill of medical teachers throughout the country who will continue to feel that there is a failure to appreciate the injustice they have experienced for many years past. They foel that there is now an excellent opportunity to rectify a long standing anomaly which has hindered the recruitment of medical teachers and has encouraged emigration.

We are convinced that the only equitable method of assimilation is to apply the principle of parity to every 
member of staff who should receive the same salary as he would have received had he been an NHS consultant.

This problem raises the difficult question of disparity of pay between different faculties of a university. We do not consider that the pay of doctors and dentists should as of right be higher than that of other university staff, but, if medical schools are to thrive, their clinical staff who are practising doctors and dentists should receive a salary which is comparable with their counterparts in the NHS.

$$
\begin{aligned}
& \text { Yours faithfully, } \\
& \text { Norman Morris (London) } \\
& \text { laN Bouchier (London) } \\
& \text { Gordon Cumming (Birmingham) } \\
& \text { Alastair Connelu (Belfast) } \\
& \text { ROBERT LOWE (London) } \\
& \text { Tain Macintyre (London) } \\
& \text { Clifford Mawdshey (Edinburgh) } \\
& \text { Sidney Truhlove (Oxford) }
\end{aligned}
$$

Executive Committee,

Association of University

Clinical Academic Staff,

Department of Obstetrics and Gynaecology,

Charing Cross Hospital Medical School,

London WC2.

\section{University News}

Dr R. M. Alexander, University College of North Wales, Bangor, has been appointed professor and head of the department of zoology at the University of Leeds.

Dr D. Shaw has been appointed to the new post of prodean of the Faculty of Science at the University of Liverpool.

\section{Appointments}

Mr Geoffrey Hubbard has been appointed director of the National Council for Educational Technology in succession to Mr R. A. Becher.

Professor N. C. Hunt, University of Edinburgh, and Professor D. Lewis, University College London, have been appointed members of the University Grants Committee. Professor J. Black, Bath University of Technology, and Mr G. S. Bosworth, Newcastle upon Tyne Polytechnic, have been reappointed to the committec.

Dr C. E. Lucas and Mr G. B. R. Feilden have been appointed to fill two places on the Council for Scientific Policy which have been vacated by Dr J. B. Adams and Lord Jackson of Burnley.

\section{Announcements}

The medal of the Society of Chemical Industry will be awarded to Professor F. Morton of the University of Manchester Institute of Science of Technology. The Platinum Medal of the Institute of Metals has been awarded to Sir Ronald Prain in recognition of his service to the non-ferrous metal industries; the institute's Rosenhain Medal has been awarded to Professor J. W. Christian, professor of physical metallurgy at the University of Oxford, in recognition of his contributions in the field of physical metallurgy; and the W. H. A. Robertson Medal has been awarded to $\mathrm{T}$. W. Allen and L. J. Cartmell for their paper "The Use of a HighSpeed Press for the Forging of Nickel-Base Alloys".

'The Councils of the Royal Society and the Australian National University are establishing a memorial fund in commemoration of Lord Florey, to be used for visiting research fellowships in the biomedical sciences between Australia and the UK. Particulars can be obtained from the Royal Society (Florey Fund), 6 Carlton House Terrace, London SW1.
The annual course for laymen in Tropical Hygiene will be held by the Ross Institute during July 7-11. Further details can be obtained from the Ross Institute of Tropical Hygiene, London School of Hygiene and Tropical Medicine, Keppel Street (Gower Street), London WC1.

The British Society for Cell Biology has formed a study group to make a survey of the teaching of cell biology to undergraduates, graduates and technicians. Those who teach courses in this subject or recruit and employ cell biologists are invited to send information to Dr L. G. F. Bell, Department of Zoology, The University, Southampton, Hampshire.

The International Union Against Cancer will be awarding the American Cancer Society Eleanor Roosevelt International Cancer Fellowships for periods of study abroad in the experimental or clinical aspects of cancer research. Further details can be obtained from International Union Against Cancer, PO Box 400, 1211 Geneva 2, Switzerland.

The National Academy of Engineering, Washington, has awarded its fourth Founders Medal to Dr H. Nyquist in recognition of his contributions to engineering.

The Institute of Physics and the Physical Society has awarded the Guthrie Medal to Professor C. F. Powell, University of Bristol, for his contributions to particle physics; the Glazebrook Medal to Lord. Penney, Imperial College, University of London, for his work on the development of nuclear explosives and other applications of atomic energy; the Thomas Young Medal to Professor G. Toraldo di Francia, University of Florence, for his work on optics and microwave physics; the Charles Ghree Medal to Professor S. K. Runcorn, University of Newcastle upon Tyne, for his work on palaeomagnetism; the Duddell Medal to Professor C. W. Oatley, University of Cambridge, for his development of the scanning electron microscope; the Bragg Medal to Mr J. L. Lewis, Malvern College, for his work on the teaching of physies in schools; and the Charles Vernon Boys Prize to Mr H. P. Rooksby, General Electric Company Ltd, for his work in X-ray crystallography.

The Geological Society of London has awarded the Wollaston Medal to Professor W. M. Ewing, University of Columbia, for his contributions to geological studies of the oceans and seismic wave propagation; the Murchison Medal to Dr P. E. Kent, British Petroleum Company Limited, in recognition of his work in economic geology and British stratigraphy; the Lyell Medal to Professor F. J. Turner, University of California, for his contributions to the study of metamorphic rocks; the Bigsby Medal to Dr R. G. West, University of Cambridge, for his work in Pleistocene stratigraphy and the vegetational history of Britain; and the Prestwich Medal to Dr L. S. B. Leakey and Mrs Mary Leakey for their contribu. tions to palaeoanthropology and to Fast African stratigraphy. The proceeds of the Society's Wollaston Fund have been awarded to Dr M. G. Audley-Charles, Imperial College, University of London, for his stratigraphical studies; the proceeds of the Murchison Fund to Dr A. Hallam, University of Oxford, for his work in stratigraphy, paiaeo-ecology and sedimentology; the Lyell Fund has been divided between Dr E. R. Oxburgh, University of Oxford, for his work on the structure of the Austrian Alps and on the flow of the Upper Mantle, and Dr N. J. Price, Imperial College, University of London, for his work on the rheological properties of rock materials.

Erratum. Dr J. G. Makari of Makari Research Laboratories Incorporated, 223 South Dean Street, Englewood, New Jersey, has written to say that the article "Produetion of Self-directed Antibody by Tumour Cells" by Dr J. Charney (Nature, 220, 504; 1968) did not refer to his earlier formulation of the concept of the formation by tumour cells of antibodies directed at the tumour cells themselves 